\title{
Incisor Size Analysis to Predict Mesiodistal Diameter in Unerupted Canine and Premolar Crowns in Native and Non-Native Chilean Population
}

\author{
Análisis del Tamaño de Incisivos para Predecir el Diámetro Mesiodistal de Coronas \\ de Caninos y Premolares No Erupcionados en Población Chilena Nativa y No Nativa
}

Alejandro Lara ${ }^{1}$; Pablo Navarro ${ }^{2} \&$ Paulo Sandoval $^{3}$

LARA, A.; NAVARRO, P. \& SANDOVAL, P. Incisor size analysis to predict mesiodistal diameter in unerupted canine and premolar crowns in native and non-native Chilean population. Int. J. Morphol., 35(4):1459-1464, 2017.

SUMMARY: The principal orthodontic problems observed in the mixed dentition phase are related to arch length and tooth size discrepancy. In order to identify such space discrepancies different methods of mixed dentition space analyses have been introduced. For this reason the purpose of this study is to generate a new regressive equation to predict the diameter of cuspid and bicuspid teeth through mesiodistal widths of lower incisors in a Chilean population sample between native and non-native population. The study was conducted at the Araucania Dental Clinic in Temuco, and the sample comprised of historical dental casts from 200 school children (93 boys and 107 girls) from Temuco, Chile, between 13-16 years of age. The native Mapuche population consisted of 107 students and the non-native of 93 students. Measurements of the mesiodistal widths of mandibular incisors, maxillary and mandibular canines and premolars were carried out with the help of Vernier gauge calipers calibrated to 0.01 of a millimeter. The results show that there are differences in the mesiodistal diameter size of incisors, and canines and premolars in the two studied groups. There is a low correlation of the variables studied. In conclusion, significant sexual dimorphism in tooth sizes exists in the native sample, and there is no difference in non-native population. It is necessary to develop a predictive formula that is greater than $70 \%$ of accuracy for clinical application. Resonance imaging (MRI).

KEY WORDS: Mixed dentition; Tooth size; Discrepance; Predictive formula.

\section{INTRODUCCIÓN}

The main orthodontic problems observed in the mixed dentition phase are related to arch length and tooth size discrepancy. In order to identify such space discrepancies different methods of mixed dentition space analyses have been introduced. The purpose of these studies is to evaluate the amount of space in the arch for the succeeding permanent teeth and occlusal adjustment (Diagne et al., 2003). Different methods of predicting the sizes of permanent canines and premolars have been published (Yuen et al., 1998). Early attempts of estimating tooth sizes by G.V. Black and others were based on tables of average mesiodistal width (Black, 1897; Sim, 1997). Other methods of prediction were based on estimating the size of permanent teeth on radiographs alone, or in combination with crown diameters measured on dental casts (Tanaka \& Johnston, 1974; Sim). One method that is widely used, correlates the mesiodistal crown diameters of erupted mandibular permanent incisors as the predictor for the size of unerupted canines and premolars (Motokawa et al., 1987). Among the different methods available Tanaka's mixed dentition analysis is probably the most widely used. Tanaka's probability tables were developed from studies conducted on Caucasian population (Ballard \& Wylie, 1947; Staley \& Hoag, 1978). This is a correlative method that uses the combined mesiodistal widths of the erupted mandibular incisors to predict mesiodistal widths of unerupted canines and premolars with the use of a prediction chart. However, the applicability of these tables to other ethnic groups has been studied and found wanting (Ferguson et al., 1978; Frankel \& Benz, 1986). It has also been well established in the literature that mesiodistal widths of teeth vary considerably between different racial groups (Bailit, 1975; Schirmer et al., 1995). Sexual dimorphism

\footnotetext{
${ }^{1}$ Dentistry Magister Program, Universidad de La Frontera, Temuco, Chile.

${ }^{2}$ Biostatistician, Dental Sciences Research Center, Faculty of Dentistry, Universidad de La Frontera, Temuco, Chile.

${ }^{3}$ Associated Professor, Paediatric and Orthodontics Department, Universidad de La Frontera, Temuco, Chile.
} 
has also been confirmed in several studies (Smith \& Shegev, 1988). The purpose of this study is to generate a new regressive equation to predict the diameter of the cuspid and bicuspid teeth, through mesiodistal width of lower incisors in a Chilean population sample, differentiating between native and non-native population.

\section{MATERIAL AND METHOD}

The study was conducted at the Araucanía Dental Clinic Temuco, from March through August 2014 (six months), and the sample comprised historical dental casts from 200 school children (93 boys and 107 girls) in the age range of 13-16. The native Mapuche population group was comprised of 107 students ( 55 male and 52 female) and the Chilean group of 93 (40 male and 53 female). Both study groups are from the Araucania region in Chile.

Selection Criteria. Dental cast were obtained from children in the age group of 13-16 years. 2. All the permanent teeth had to be present in each arch and be fully erupted (with the exception of third molars) 3 . Permanent teeth had to be caries free. 4. No more than minor malocclusion or mild crowding or spacing could be present. 5. Children with congenital craniofacial anomalies or previous history of orthodontics were excluded. 6. Children with restorations or significant attrition were excluded.

Of the selected children we used casts of maxillary and mandibular arches that were obtained with alginate impression material. Study models were then carefully prepared using dental stone plaster. A standardized method was used to measure the mesiodistal crown widths (Moorrees \& Reed, 1964). The greatest mesiodistal crown width of each tooth was measured between its contact points, with the Vernier gauge calipers placed parallel to the occlusal and vestibular surfaces. This method was reported to be highly accurate for measuring mesiodistal crown widths (Doris et al., 1981). Measurements of the mesiodistal widths of mandibular incisors, maxillary and mandibular canines and premolars were made with the help of Vernier gauge calipers (Uyustools, China) calibrated to 0.01 of a millimeter. Measurement reliability was checked according to a method suggested by Lundstrom, where a single investigator does all the measurements, after carefully marking the maximum mesiodistal width on the teeth to be measured, and then re-measures certain randomly selected casts (Hixon \& Oldfather, 1958). The coefficient of test reliability on 20 such randomly selected casts (each 10th cast was selected) was calculated. R-value was 0.97 hence reliability was confirmed.
The sum of the mesiodistal measurements of the following groups of teeth was pooled and the means were calculated: The four mandibular incisors, the mandibular canines and premolars, the maxillary canines and premolars in each quadrant. These data were then used for regression equation that could be used clinically for the prediction of tooth size.

Statistical Analysis. The data collected was subjected to statistical analysis using SPSS 23.0 IBM for Windows (Statistical Package for Social Sciences, CA).

\section{RESULTS}

The results of the study are presented as follows: The sample has been categorized in sub-groups by sex and native Mapuche and non-native Chilean population to generate a regressive linear equation for each one (Table I). For purposes of this study the canine and premolars are called cuspids and bi-cuspids respectively.

Measurements of the mesiodistal widths of the teeth are summarized in Tables II, III and IV.

In reference to the data on tooth size of the Mapuche population sample, the average value is lower, both in the sum of incisors and the upper and lower canines and premolars, compared to the non-Mapuche population. However, their dispersion is greater.

There are significant differences in tooth size of lower incisors only between the total Mapuche and nonMapuche populations, however there are no significant differences between mapuche and non-mapuche boys and girls (Table III and Fig. 1).

We observed significant differences in the upper canines and premolar diameters for the entire Mapuche and non-Mapuche populations. However, there were no differences noted between the non-Mapuche boys and girls (Table IV and Fig. 4).

There are significant differences in the diameter of the lower canines and premolars, as well as between Mapuche and non-Mapuche boys and girls (Table V).

It can be seen that the relation between lower incisors and the sum of canines and premolars is positive, which indicates that the larger the size of the lower incisors, the size of the lateral areas is also larger. 
However, the relation values being low, less than 0.8 , indicate that the dispersion is broad enough to determine predictability from the size of the lower incisors.

From the results in Tables II, III and IV, it can be ascertained that there are differences in the sum of the size of both incisors, as well as canines and premolars in the two ethnic variables considered, where values tended to be lower in all cases analyzed in the Mapuche population sample.

The relation between the mesiodistal width of erupted mandibular incisors and mesiodistal width of erupted canines and premolars allows for the development of a predictive equation with appropriate significant values (Tables V to VIII).

The linear regression equations, based on dental measurements were developed for predicting the sum of mesiodistal widths of unerupted canine and premolars for both maxillary and mandibular dental arches during the mixed dentition period.
The following are the equations in this study for prediction:

The equation is $Y=a+b(x)$

For LCPM width Males and Females in non-Mapuche

1. $\mathrm{Y}=2.254+0.438(\mathrm{x})$

For UCPM width Males and Females in non-Mapuche

1. $\mathrm{Y}=3.265+0.380(\mathrm{x})$

For UCPM width in Mapuche

1. $\quad \mathrm{Y}=4.448+0.323(\mathrm{x})-$ Males

2. $\quad \mathrm{Y}=4.603+0.313(\mathrm{x})-$ Females

For LCPM width in Mapuche

3. $\mathrm{Y}=2.491+0.418(\mathrm{x})-$ Males

4. $\mathrm{Y}=4.064+0.347(\mathrm{x})-$ Females

Table I. Descriptive statistics of the Mapuche population sample distributed by sex.

\begin{tabular}{lcll}
\hline Group of teeth & $\begin{array}{r}\text { Male and Female } \\
\text { Mean/ SD }\end{array}$ & $\begin{array}{l}\text { Male } \\
\text { Mean/ SD }\end{array}$ & $\begin{array}{l}\text { Female } \\
\text { Mean/ SD }\end{array}$ \\
\hline Lower Incisors & $11.53 / 0.82$ & $11.66 / 0.82$ & $11.40 / 0.8$ \\
LCPM (mm) & $21.53 / 1.29$ & $21.90 / 1.23$ & $21.13 / 1.23$ \\
UCPM $(\mathrm{mm})$ & $22.01 / 1.26$ & $22.29 / 1.23$ & $21.71 / 1.22$ \\
\hline
\end{tabular}

LCPM: Lower canine and bi-cuspids. UCPM: Upper canine and bi-cuspids.

Table II. Descriptive statistics of the non-Mapuche population sample distributed by sex.

\begin{tabular}{llll}
\hline Groups of teeth & $\begin{array}{l}\text { Male and Female } \\
\text { Mean/ SD }\end{array}$ & $\begin{array}{l}\text { Male } \\
\text { Mean/ SD }\end{array}$ & $\begin{array}{l}\text { Female } \\
\text { Mean/ SD }\end{array}$ \\
\hline Lower Incisors & $11.97 / 0.68$ & $12.06 / 1.31$ & $11.9 / 1.41$ \\
LCPM & $22.10 / 0.98$ & $22.4 / 1.09$ & $21.87 / 0.83$ \\
UCPM & $22.77 / 1.20$ & $22.99 / 1.34$ & $22.55 / 0.99$ \\
\hline
\end{tabular}

LCPM: Lower canine and bi-cuspids. UCPM: Upper canine and bi-cuspids.
Table III. Tooth size of lower incisors of the Mapuche and non-Mapuche populations.

\begin{tabular}{lc}
\hline Non-Mapuche $v s$ Mapuche & $\mathrm{p}$ \\
\hline Male Female Mapuche & $0,001^{*}$ \\
Male Female Non-Mapuche & 0,1 \\
Non-Mapuche $v$ s Mapuche & 0,161 \\
\hline *: Significant differences &
\end{tabular}

Table IV. Relation of the upper canines and premolars diameters for the total of the Mapuche and non-Mapuche population.

\begin{tabular}{ll}
\hline RELATION( $1,3-1,4-1,5)$ & $\mathrm{p}$ \\
\hline Non-Mapuche $v s$ Mapuche & $0,001^{*}$ \\
Male Female Mapuche & $0,017^{*}$ \\
Male Female Non-Mapuche & 0,129 \\
\hline
\end{tabular}

* Significant differences
Table V. Relation of the diameter of the lower canines and premolars in Mapuche and nonMapuche population.

\begin{tabular}{lc}
\hline RELATION $(4,3-4,4-4,5)$ & $\mathrm{p}$ \\
\hline Non-Mapuche $v s$ Mapuche & $0,001^{*}$ \\
Male Female Mapuche & $0,002^{*}$ \\
Male Female Non-Mapuche & $0,012^{*}$ \\
\hline * Significant differences
\end{tabular}


Table VI. Analysis of dental sizes of lower incisors, relative to the sum of the maxillary and mandibular canines and premolars of Mapuche and non-Mapuche subjects, divided by sex.

\begin{tabular}{llccllll}
\hline Variables & Sex & Constant (a) & Constant (b) & p & R & F & Sig \\
\hline UCPM & M & 4.868 & 0.312 & $<0.05$ & 0.635 & 26.403 & 0.001 \\
UCPM & F & 1.529 & 0.456 & $<0.05$ & 0.690 & 46.449 & 0.001 \\
LCPM & M & 3.823 & 0.367 & $<0.05$ & 0.609 & 22.950 & 0.001 \\
LCPM & F & -0.017 & 0.542 & $<0.05$ & 0.645 & 36.393 & 0.001 \\
\hline
\end{tabular}

$\mathrm{p}<0,05$ LCPM: Lower canine and bi-cuspids. UCPM: Upper canine and bi-cuspids.

Table VII. Analysis of dental sizes of lower incisors, relative to the sum of canines and maxillary and mandibular premolars of Mapuche subjects, divided by sex.

\begin{tabular}{lcccllll}
\hline Variables & Sex & Constant (a) & Constant (b) & p & R & F & Sig \\
\hline UCPM & M & 4.448 & 0.323 & $<0.05$ & 0.484 & 16.251 & 0.00 \\
UCPM & F & 4.403 & 0.313 & $<0.05$ & 0.479 & 14.914 & 0.00 \\
LCPM & M & 2.491 & 0.418 & $<0.05$ & 0.626 & 34.162 & 0.00 \\
LCPM & F & 4.064 & 0.347 & $<0.05$ & 0.535 & 20.053 & 0.00 \\
\hline
\end{tabular}

UCPM: Upper canine and bi-cuspids. LCPM: Lower canine and bi-cuspids

Table VIII. Analysis of dental sizes of lower incisors, relative to the sum of canines and maxillary and mandibular premolars of non-Mapuche subjects, divided by sex.

\begin{tabular}{llllllll}
\hline Variables & Sex & Constant (a) & Constant (b) & $\mathrm{p}$ & $\mathrm{R}$ & $\mathrm{F}$ & $\mathrm{Sig}$ \\
\hline UCPM & $\mathrm{M}$ & 4.868 & 0.312 & $<0.05$ & 0.635 & 26.403 & 0.001 \\
UCPM & $\mathrm{F}$ & 1.529 & 0.456 & $<0.05$ & 0.690 & 46.449 & 0.001 \\
LCPM & $\mathrm{M}$ & 3.823 & 0.367 & $<0.05$ & 0.609 & 22.950 & 0.001 \\
LCPM & $\mathrm{F}$ & -0.017 & 0.542 & $<0.05$ & 0.629 & 60.219 & 0.001 \\
\hline
\end{tabular}

UCPM: Upper canine and bi-cuspids. LCPM: Lower canine and bi-cuspids

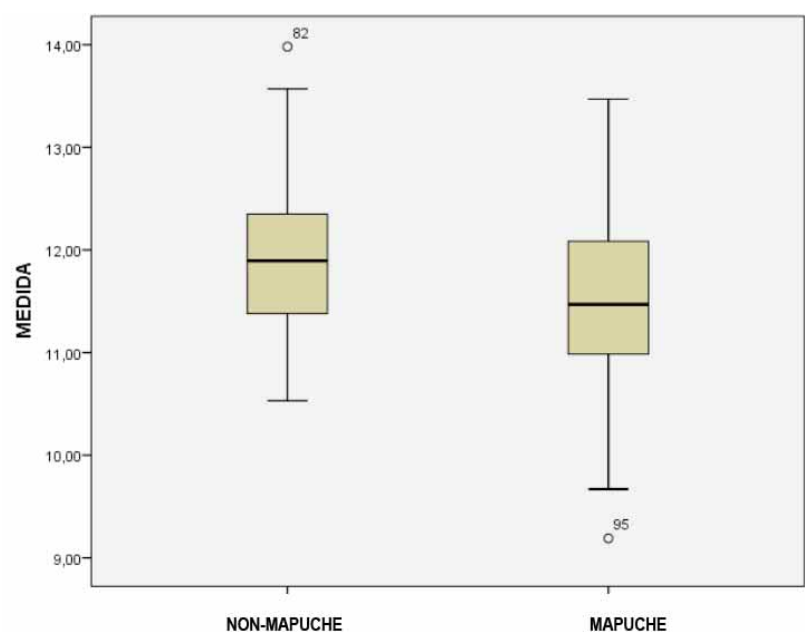

Fig. 1. Tooth diameter 4.1 and 4.2 in Mapuche and non-Mapuche.

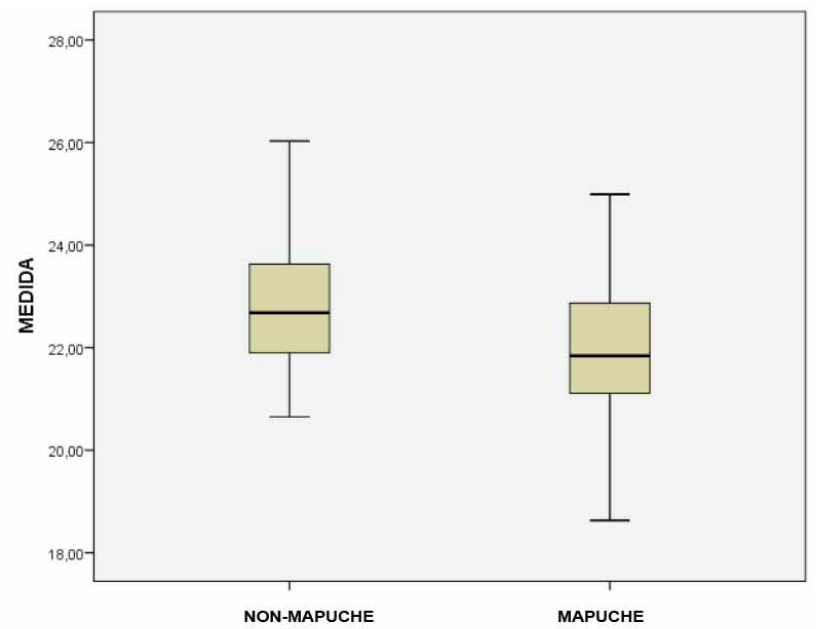

Fig. 2. Tooth diameter $1.3,1.4$ and 1.5 in Mapuche and nonMapuche. 


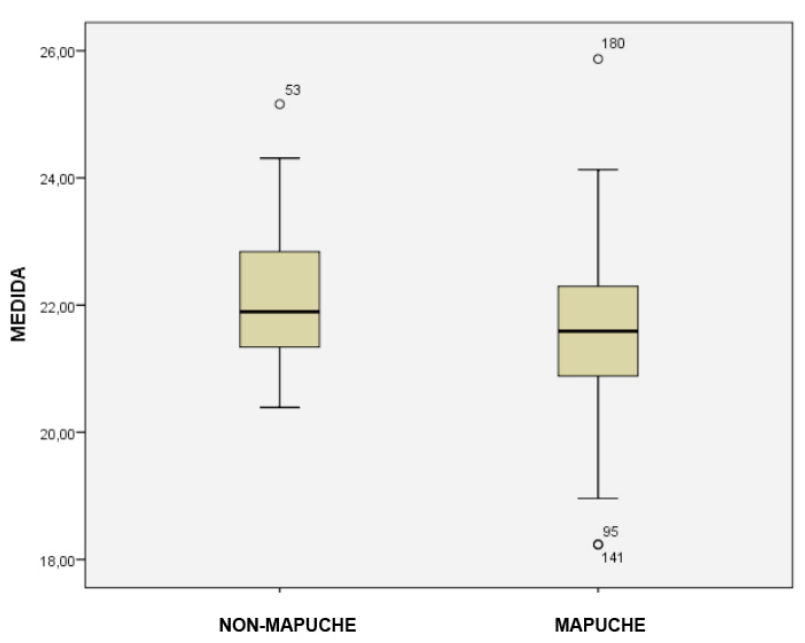

Fig. 3. Tooth diameter $1.3,1.4$ and 1.5 in Mapuche and nonMapuche

\section{DISCUSSION}

This study was done to assess the reability of the Tanaka prediction as well as generate a regression equation suitable for the local ethnic population. In order to ensure the reliability of the data a sufficiently large sample size was included $(n=200)$, they were aged between 13 to 16 years.

Definite racial and ethnic differences in tooth size have been emphasized in several studies (Schirmer et al.; Melgaço et al., 2007). The prediction tables formulated at the University of Michigan, which are based on data derived from population of Northern European descent, is neither accurate nor applicable when applied to a population of different ethnic origin.

Contrary to Smith \& Schirmer (Smith \& Shegev) in this study we found that the non-native population has no significant difference according to sex in the tooth size.

Multiple regression analysis have indicated that the sum of the mesiodistal width of the four mandibular permanent incisors, are the best predictors for unerupted canines and premolars (Tanaka, 1988; Philip et al., 2010). Fortunately, these are the first teeth to erupt during early mixed dentition. It is the accessibility of Tanaka's tables that makes them clinically attractive and popular, and an effective method to predict the mesiodistal dimensions of unerupted maxillary and mandibular canines and premolars. However, this formula does not apply to other populations.
The predicted sum of the mesiodistal widths of unerupted canines and premolars can be read at the probability level of the practitioner choice. The $75 \%$ percentile level is recommended by Moyers and is generally used. This means that in $75 \%$ of cases, the unerupted canines and premolars will be at the predicted value or less (Gardner, 1978).

Realizing the importance of diagnosing the arch size to tooth size discrepancy at an early stage, many investigators have formulated criteria for predicting the size of unerupted permanent teeth (Bernabé \& Flores-Mir, 2005). Moyers (1992) prediction tables were mainly formulated for white Americans and he chose the $75 \%$ level of probability since it was most practical from the clinician's stand point. Moyers sample has not been characterized in the literature. While applying Moyers prediction tables to a section of the south Indian population, Rani \& Goel (1988) found it to be more applicable at the $35 \%$ level instead of $75 \%$ as observed by Moyers for his sample. Priya \& Munshi (1994) formulated a prediction chart for mixed dentition analysis, Aggarwal \& Chopra (1981) formulated their own prediction tables and graphs for a section of the North Indian population. The present study showed that $58 \%$ probability is more applicable for the maxillary arches in native population, and $66 \%$ for mandibular teeth. The $67 \%$ probability is more applicable for maxillary arches in non-native population and $62 \%$ for mandibular teeth. Since the literature is scarce in the formulation of such regression equation for different populations, considering racial, geographic and other differences from those of the north Americans, the present study attempted to formulate a regression equation for the children of the Araucanía Region in Chile.

\section{CONCLUSION}

In this study we found that significant sexual dimorphism in tooth sizes exist in the native sample, and that there is no difference in the non-native population. As the regression equation was formulated based on data from local population, it is more accurate than the international formula used nowadays. It is necessary to find a predictive formula greater than $70 \%$ accuracy for clinical application.

LARA, A.; NAVARRO, P. \& SANDOVAL, P. Análisis del tamaño de incisivos para predecir el diametro mesiodistal de coronas de caninos y premolares no erupcionados en población chilena nativa y no nativa. Int. J. Morphol., 35(4):1459-1464, 2017.

RESUMEN: El principal problema ortodóncico observado en la etapa de dentición mixta está relacionado con la longitud 
del arco y la discrepancia del tamaño de los dientes. En orden a identificar tal discrepancia de espacio, diferentes métodos de análisis de espacio en dentición mixta han sido introducidos. Por esta razón el objetivo de este estudio fue generar una nueva ecuación regresiva para predecir el diámetro mesiodistal de caninos y premolares a partir del ancho de los incisivos centrales inferiores en una muestra de población chilena nativa y no nativa. El estudio fue realizado en la Clínica de Ortodoncia Araucanía en Temuco. La muestra fue seleccionada de una colección histórica de modelos dentales, 200 escolares (93 niños y 107 niñas) de la ciudad de Temuco, Chile con edades entre 13 y16 años. La población nativa fueron 107 estudiantes Mapuches y los no nativos fueron 93 estudiantes. Las mediciones del ancho mesiodistal de los incisivos mandibulares, caninos maxilares and mandibulares y premolares fueron realizadas con la ayuda de un medidor Vernier calibrado a 0.01 de milímetro. Los resultados muestran que hay diferencias en el diámetro mesiodistal de incisivos, y caninos y premolares en los grupos estudiados. Hay una baja correlación de las variables estudiadas. En conclusión, hay diferencias significativas en el tamaño de dientes entre hombres y mujeres en la muestra de nativos, y no hay diferencias en la población no nativa. Es necesario desarrollar una fórmula predictiva que sea mayor a $70 \%$ de seguridad para aplicaciones clínicas.

PALABRAS CLAVE: Dentición mixta; Tamaño del diente; Discrepancia; Fórmula predictiva.

\section{REFERENCES}

Aggarwal, S. P. \& Chopra, K. K. A simple method of prediction of cuspid and bicuspid widths. J. Ind. Dent. Assoc., 53:113-5, 1981.

Bailit, H. L. Dental variation among populations. An anthropologic view. Dent. Clin. North Am., 19(1):125-39, 1975.

Ballard, M. L. \& Wylie, W. L. Mixed dentition case analysis, estimating size of unerupted permanent teeth. Am. J. Orthod., 33(11):754-9, 1947.

Bernabé, E. \& Flores-Mir, C. Are the lower incisors the best predictors for the unerupted canine and premolars sums? an analysis of a Peruvian sample. Angle Orthod., 75(2):202-7, 2005.

Black, G. V. Descriptive Anatomy of Human Teeth. $4^{\text {th }}$ ed. Philadelphia, S. S. White Dental Manufacturing, 1897. pp.16.

Diagne, F.; Diop-Ba, K.; Ngom, P. I. \& Mbow, K. Mixed dentition analysis in a Senegalese population: elaboration of prediction tables. Am. J. Orthod. Dentofacial Orthop., 124(2):78-83, 2003.

Doris, J. M.; Bernard, B. W.; Kuftinec, M. M. \& Stom, D. A biometric study of tooth size and dental crowding. Am. J. Orthod., 79(3):32636, 1981.

Ferguson, F. S.; Macko, D. J.; Sonnenberg, E. M. \& Shakun, M. L. The use of regression constants in estimating tooth size in a Negro population. Am. J. Orthod., 73(1):68-72, 1978.

Frankel, H. H. \& Benz, E. M. Mixed dentition analysis for black Americans. Pediatr. Dent., 8(3):226-30, 1986.

Gardner, R. B. A comparison of four methods of predicting arch length. Am. J. Orthod., 75(4):387-98, 1978.

Hixon, E. H. \& Oldfather, R. E. Estimation of the sizes of unerupted cuspid and bicuspid teeth. Angle Orthod., 28(4):236-40, 1958.

Melgaço, C. A.; de Sousa Araújo, M. T. \& de Oliveira Ruellas, A. C. Mandibular permanent first molar and incisor width as predictor of mandibular canine and premolar width. Am. J. Orthod. Dentofacial Orthop., 132(3):340-5, 2007.
Moorrees, C. F. \& Reed, R. B. Correlations among crown diameters of human teeth. Arch. Oral Biol., 9:685-97, 1964.

Motokawa, W.; Ozaki, M.; Soejima, Y. \& Yoshida, Y. A method of mixed dentition analysis in the mandible. A. S. D. C. J. Dent. Child., 54(2):1148, 1987.

Moyers, R. Manual de Ortodoncia. Buenos Aires, Médica Panamericana, 1992.

Philip, N. I.; Prabhakar, M.; Arora, D. \& Chopra, S. Applicability of the Moyers mixed dentition probability tables and new prediction aids for a contemporary population in India. Am. J. Orthod. Dentofacial Orthop., 138(3):339-45, 2010.

Priya, S. \& Munshi, A. K. Formulation of a prediction chart for mixed dentition analysis. J. Indian Soc. Pedod. Prev. Dent., 12(1):7-11, 1994.

Rani, M. S. \& Goel, S. Evaluation of Moyers mixed dentition analysis for South Indian population. J. Indian Dent. Assoc., 60(12):253-5, 1988.

Schirmer, U. R.; Malan, J. A. \& Viljoen, E. E. Comparison of mesiodistal crown dimensions of South African Blacks \& Whites. J. Dent. Res., 74:10-20, 1995.

Sim, J. M. Minor tooth movements in children. $2^{\text {nd }}$ ed. St. Louis, Mosby, 1977. pp.74-81.

Smith, P. A. \& Shegev, M. The dentition of Nubians from Wadi Halfa, Sudan: An evolutionary perspective. J. Dent. Assoc. S. Afr., 43(11):53541, 1988.

Staley, R. N. \& Hoag, J. F. Prediction of the mesiodistal widths of maxillary permanent canines and premolars. Am. J. Orthod., 73(2):169-77, 1978.

Tanaka, M. M. \& Johnston, L. E. The prediction of the size of unerupted canines and premolars in a contemporary orthodontic population. $J$. Am. Dent. Assoc., 88(4):798-801, 1974.

Tanaka, R. E. Handbook of Orthodontics. $4^{\text {th }}$ ed. Year Book Medical Publishers, 1988. pp.221-46.

Yuen, K. K.; Tang, E. L. \& So, L.L. Mixed dentition analysis for Hong Kong Chinese. Angle Orthod., 68(1):21-8, 1998.

Corresponding author:

Paulo Sandoval

Associate Professor

Paediatric and Orthodontics Department

Universidad de La Frontera

Temuco

CHILE

E-mail: paulo.sandoval@ufrontera.cl

Received: 16-08-2017

Accepted: 25-10-2017 